\author{
Marquette University \\ e-Publications@Marquette
}

\title{
The Effects of Disclosure Type and Audit Committee Expertise on Chief Audit Executives' Tolerance for Financial Misstatements
}

Carolyn S. Norman

Virginia Commonwealth University

Jacob M. Rose

University of New Hampshire - Main Campus

Ikseon Suh

Marquette University, ikseon.suh@marquette.edu

Follow this and additional works at: https://epublications.marquette.edu/account_fac

Part of the Accounting Commons

\section{Recommended Citation}

Norman, Carolyn S.; Rose, Jacob M.; and Suh, Ikseon, "The Effects of Disclosure Type and Audit Committee Expertise on Chief Audit Executives' Tolerance for Financial Misstatements" (2011). Accounting Faculty Research and Publications. 55.

https://epublications.marquette.edu/account_fac/55 
Marquette University

e-Publications@Marquette

\section{Accounting Faculty Research and Publications/College of Business Administration}

This paper is NOT THE PUBLISHED VERSION; but the author's final, peer-reviewed manuscript. The published version may be accessed by following the link in the citation below.

Accounting, Organizations and Society, Vol. 36, No. 2 (February 2011): 102-108. DOI. This article is (C) Elsevier and permission has been granted for this version to appear in e-Publications@Marquette.

Elsevier does not grant permission for this article to be further copied/distributed or hosted elsewhere without the express permission from Elsevier.

\section{The Effects of Disclosure Type and Audit Committee Expertise on Chief Audit Executives' Tolerance for Financial Misstatements}

\section{Carolyn Strand Norman}

Department of Accounting, School of Business, Virginia Commonwealth University, Richmond, VA Jacob M. Rose Department of Accounting and Finance, Whittemore School of Business \& Economics, University of New Hampshire, Durham, NH

Ik Seon Suh

Department of Accounting, College of Business Administration, Marquette University, Milwaukee, WI 


\section{Abstract}

This study involves an experiment where 73 Chief Audit Executives and deputy Chief Audit Executives determine the amount of adjustment required to correct a misstatement. We manipulate the financial reporting location of the misstatement (recognized vs. disclosed) and the level of audit committee expertise (high vs. low). The results indicate that financial reporting location has significant effects on internal auditors' decisions to correct misstatements. Specifically, internal auditors are more willing to waive disclosed misstatements relative to recognized misstatements. Contrary to expectations, the results do not indicate that increased audit committee expertise and associated increases in audit committee members' perceived powers cause internal auditors to be less willing to waive misstatements.

\section{Research highlights}

- CAEs tolerate more misstatement in disclosed amounts than in recognized amounts. Increased audit committee financial expertise increases CAE's perceived power. Audit committee expertise does not lead to larger misstatement corrections. Internal and external auditors act to decrease the reliability of disclosed amounts.

\section{Introduction}

The reporting location of misstatements influences external auditors' decisions to require adjustments of these misstatements. Specifically, Libby, Nelson, and Hunton (2006) find that external audit partners are more willing to waive misstatement corrections for disclosed than for recognized amounts. This willingness to allow misstatements may increase management's incentives to manipulate disclosed amounts and increase the levels of error and bias in disclosed information. While external auditors are more willing to waive disclosed amounts, relative to recognized amounts, internal auditors may require management to adjust misstatements regardless of their reporting locations. If internal auditors do not tolerate misstatements that are disclosed, this will increase the reliability (i.e., decrease the random error and bias) of disclosed amounts and decrease the likelihood of management manipulation of disclosed amounts. As a result, the impact to practice of external auditors' willingness to waive misstated disclosures could be mitigated or even eliminated by internal audit oversight.

We examine Chief Audit Executives' and deputy Chief Audit Executives' decisions to require adjustments of misstatements that are either recognized or disclosed. Chief Audit Executives (CAEs) may require equivalent adjustments for recognized and disclosed amounts, and act to counter the actions of management and external auditors. Thus, the problems identified by Libby et al. (2006) may be partially or entirely offset by the actions of internal auditors. Alternatively, CAEs may take the same position as external auditors and be willing to waive adjustments of disclosed amounts. In either case, understanding the decision processes of CAEs will help to inform regulators and standard setters of the underlying factors that drive financial statement reliability.

While internal auditors do not face the same incentives to acquiesce to management's objections to correct misstatements as do external auditors (i.e., the risk of client loss), internal auditors' judgments and decisions are not exempt from the effects of incentives (e.g., Braiotta, 2004, Institute of Internal Audit Research Foundation, 2001, Sarens and De Beelde, 2006a, Van Peursem, 2005). Internal auditors work for management and internal auditors' performance evaluations, compensation, and job security are all controlled or influenced by management. As a result, management has power over the internal audit function, and internal auditors face pressure to comply with management objections to correct misstatements. In this study, we examine whether internal auditors are willing to allow more misstatements in disclosed amounts than in recognized amounts, and we investigate whether audit committee expertise can act to limit management's power and influence over internal auditors' decisions. 
This study employs the decision task from Libby et al. (2006) where participants must decide to adjust or waive a misstatement that involves either recognition (capital lease) or disclosure (operating lease). We replicate this task because it has been vetted, it allows us to benchmark our results against prior findings for external auditors, and the nature of lease assets and liabilities involves little subjectivity and measurement uncertainty. We add a manipulation of audit committee expertise (low vs. high) to the existing task to create a $2 \times 2$ betweenparticipants design.

The results of our study indicate that reporting location has a significant effect on internal auditors' decisions. Specifically, CAEs and their deputies require lesser amounts of misstatement correction of disclosed amounts relative to recognized amounts. The misstatement correction result mirrors the findings for external auditors (Libby et al., 2006). While increased audit committee expertise increases audit committee members' perceived power over management, we do not find that CAEs require greater misstatement corrections when the audit committee has more financial expertise, relative to less expertise. It appears that internal auditors may not have enough concern about disclosed misstatements to warrant a decision to exercise the power they derive from audit committee expertise. Our results suggest that internal auditors, like external auditors and managers, act to decrease the perceived and actual reliability of disclosed information. Further, increasing the power of the internal audit function does not mitigate this problem.

\section{Literature review and hypotheses}

\section{Misstatements and financial reporting location}

Misstatements are any errors, certain illegal acts, and fraud that reflect control deficiencies (Public Company Accounting Oversight Board, 2007, Ramos, 2006). Once auditors detect a misstatement, they make a decision to either allow the misstatement or require adjustments of the misstatement by evaluating its materiality (SFAC No. 2, FASB, 1980). Nelson, Smith, and Palmrose (2005) indicate that such judgments can be influenced by conflicting incentives (e.g., litigation risk vs. risk of client loss). Clients' objections to any adjustments or unintentional income-increasing misstatements also affect external auditors' decisions, particularly when the potential litigation risk in the client's industry is high (e.g., Barron et al., 2001, Braun, 2001, Farmer et al., 1987, Libby and Kinney, 2000, Libby et al., 2006, Nelson et al., 2002, Nelson et al., 2005, Ng and Tan, 2003). Libby et al. (2006) examine whether the financial reporting location of misstatements in the financial statements (i.e., recognized vs. disclosed misstatements) influences the amount of misstatement correction required by external auditors. The authors find that external audit partners tolerate disclosed misstatements more than recognized misstatements when management objects to misstatement correction.

Schipper (2007) refers to the findings of Libby et al. (2006) to explain external auditors' speculative behaviors regarding users' reliance on recognized vs. disclosed information. Schipper suggests that one reason external audit partners allow disclosed misstatements more than recognized misstatements is because they anticipate the materiality threshold is higher for the former than for the latter. Concurrently, they expect a lower potential risk of litigation (or reputation loss) associated with tolerating disclosed misstatement amounts than for tolerating recognized misstatement amounts.

Like external auditors, internal auditors face conflicts of interest that may threaten their independence and objectivity (Institute of Internal Audit Research Foundation, 2001, Van Peursem, 2005). Management exerts significant power over internal audit because management controls or influences internal audit's budget, pay, performance evaluations, workload, and job security (Braiotta, 2004, Chadwick, 1995, Institute of Internal Auditors, 2002, McHugh and Raghunandan, 1994, Turley and Zaman, 2007, Raghunandan et al., 2001, Sarens and De Beelde, 2006a). Management's powers over internal audit suggest that internal auditors are motivated to take positions that benefit management's interests. As a result, when management opposes misstatement 
corrections, internal auditors may be reluctant to correct misstatements. On the other hand, internal auditors' stature also depends on their expertise and performance in monitoring internal controls and financial reporting quality, and internal auditors' compensation, performance evaluations, workload, etc. are also influenced by the audit committee (Sarens \& De Beelde, 2006b). Thus, internal auditors face potentially conflicting motivations to please management, please the audit committee and promote reliable financial reports.

To balance these conflicting incentives, we propose that internal auditors will require more corrections of recognized misstatements than they will require for disclosed misstatements. Internal auditors will adopt the decision strategy to tolerate more misstatements of disclosed amounts because this strategy limits the potential for restatements and adverse investor, creditor, or audit committee reactions that can result from misstated and recognized amounts (Scholz, 2008) while also preserving some of the benefits of a good relationship with management (e.g., reputation enhancement and increased incentive-based-compensation). This discussion leads to the following hypothesis.

$\mathrm{H} 1$ : Internal auditors will require management to make larger corrections when misstatements are recognized relative to when misstatements are disclosed.

\section{Effects of audit committee expertise on internal auditors' decisions}

Internal audit evaluates and works to improve the effectiveness of control, risk management, and governance processes (IIA, 2008). Internal audit also helps an organization to accomplish its goals, such as the effectiveness and efficiency of operations, the reliability of financial reporting, and compliance with applicable laws and regulations. While carrying out its functions, internal audit is responsible for providing independent, objective opinions and advice to client-management. The individual who heads up the internal audit function is normally called the Chief Audit Executive (CAE), but this position may carry a variety of different titles, such as internal audit director, general auditor, head of internal audit, chief internal auditor, and inspector general.

In addition to its supportive role with management, internal audit assists the audit committee to oversee an organization's audit and control functions (Arens et al., 2009, Braiotta, 2004, Gramling et al., 2004, Institute of Internal Audit Research Foundation (IIARF), 2003a, Sarens and De Beelde, 2006b). Prior to enactment of the Sarbanes-Oxley Act (SOX), internal audit's proximity with management raised concerns about potential impairment of its independence and objectivity (IIARF, 2001). Even post-SOX, doubts about internal audit's independence and objectivity have persisted (e.g., Drexler, 2003, Glascock, 2002, Harrington et al., 2005, Institute of Internal Audit Research Foundation (IIARF), 2003b, Kawashima, 2007, Rodgers, 2003). In response to these concerns, the Institute of Internal Auditors (IIA) recommended that the CAE functionally report to the audit committee or its equivalent, and administratively report to the CEO of the organization

(Braiotta, 2004, Institute of Internal Auditors (IIA), 2008, Institute of Internal Audit Research Foundation (IIARF), 2003b), and this position has been supported by external auditors as well (KPMG., 2008). Criticisms of internal audit independence and potential conflicts of interest still persist even after the IIA's dual reporting recommendations (e.g., Jameson, 2006, Johnson, 2006).

The IIA believes that effective audit committees allow internal auditors to better maintain their independence and objectivity and promote quality financial reporting (Braiotta, 2004, Institute of Internal Auditors (IIA), 2008, Institute of Internal Audit Research Foundation (IIARF), 2003a, Institute of Internal Audit Research Foundation (IIARF), 2003b). To support the IIA assertion, it is important to understand how internal auditors, in particular CAEs, perceive management from a power-dependence perspective and what dimensions of audit committee power (e.g., expertise) alter these perceptions.

Power is defined as the capacity or potential to influence others' attitudes or behaviors despite resistance (Bacharach and Lawler, 1980, Emerson, 1962, Finkelstein, 1992, Pfeffer, 1981). Internal auditors perceive 
management to be powerful and may perceive the need to acquiesce to management desires because internal auditors value the outcomes provided by management (Bacharach and Lawler, 1980, Lawler and Bacharach, 1979). However, internal auditors will perceive management to be less powerful if a third party, such as the audit committee, has the ability to influence these outcomes (Bacharach and Lawler, 1980, Lawler and Bacharach, 1979). Thus, power theory indicates that the presence of the audit committee can decrease the power management holds over internal audit.

To assess their dependence on management, internal auditors need to evaluate management's powers. Currently, management controls decisions pertaining to the appointment, remuneration, and dismissal of CAEs (Braiotta, 2004, Institute of Internal Auditors, 2002, McHugh and Raghunandan, 1994, Raghunandan et al., 2001, Turley and Zaman, 2007). Management evaluates internal audit performance and can promote internal auditors to high-level managerial positions (Chadwick, 1995, McHugh and Raghunandan, 1994, Sarens and De Beelde, 2006a, Turley and Zaman, 2007). Management also participates in internal audit planning for both review and approval (Institute of Internal Auditors (IIA), 2008, Sarens and De Beelde, 2006a). Moreover, internal audit day-to-day activities depend on the extent to which management supports the internal audit position, particularly CAEs' stature, within an organizational structure (Sarens \& De Beelde, 2006b). Finally, management allocates budgets for internal audit, pays compensations and provides internal audit with personnel, information, and documentation necessary to achieve its functions (McHugh and Raghunandan, 1994, Sarens and De Beelde, 2006b, Turley and Zaman, 2007). It is clear that management exerts significant power over the internal audit function.

However, the audit committee can limit management's powers when the audit committee has the ability to influence the nature of the relationship between management and internal auditors (Bacharach and Lawler, 1980, Lawler and Bacharach, 1979). Kalbers and Fogarty (1993) find that the financial expertise of audit committee members significantly enhances and signals the audit committee's power to both managers and auditors. Thus, Kalbers and Fogerty (1993) find that managers and internal auditors recognize expertise as a source of audit committee power, and the power literature indicates that as the power of the audit committee increases management will have less ability to influence internal auditors' decisions. Taken together, the literatures indicate that internal auditors will perceive the audit committee to be more powerful in the financial reporting process when audit committee financial expertise is higher, and internal auditors will be less likely to acquiesce to management pressures to avoid misstatement correction when audit committee expertise is higher. The above arguments lead to the following hypothesis:

H2: Increased audit committee expertise will decrease internal auditors' willingness to waive all misstatements.

We also expect that the effects of audit committee power on internal auditors' decisions will be more pronounced for disclosed misstatements, relative to recognized misstatements, because prior research indicates that auditors have low tolerance for recognized misstatements (Libby et al., 2006).

H3: Increased audit committee expertise will decrease internal auditors' willingness to waive disclosed misstatements more than recognized misstatements.

\section{Experimental design and method}

\section{Participants}

The participants are 76 Chief Audit Executives (CAEs) and deputy CAEs. CAEs and deputy CAEs are the ultimate decision makers in internal audit. These individuals make the decision to require or not require adjustments of misstatements in practice. In addition, CAEs and deputy CAEs interact directly with top management and the 
audit committee. Thus, the sample is composed of real-world experts for our decision context. Three participants failed to respond to all of the questions used in the models for hypothesis testing. The 73 participants included in the analyses are all Chief Audit Executives and the first Deputies to the CAE. None of these participants are from outsourced internal audit departments. The average number of years of internal audit experience is 13.71. Table 1 presents demographic data.

Table 1. Demographic information.

\begin{tabular}{|l|l|}
\hline Stature within organization & \\
\hline Chief Audit Executives vs. Deputies & $25(34.2 \%)$ vs. 48 (65.8\%) \\
\hline Professional designations (frequency and percentage) & \\
\hline Certified Internal Auditor & $23(31.5 \%)$ \\
\hline Certified Public Accountant & $50(68.5 \%)$ \\
\hline Other Certification* & $34(46.6 \%)$ \\
\hline Accounting experience (mean and standard deviation) & \\
\hline Number of years of internal audit experience & $13.71(7.98)$ \\
\hline Number of years of external audit experience & $3.08(4.72)$ \\
\hline Number of years of corporate accounting experience & $3.10(5.06)$ \\
\hline Number of years of other accounting experience & $0.62(2.03)$ \\
\hline Experience with current company (mean and standard deviation) & \\
\hline Number of years with current company (years) & $12.03(8.72)$ \\
\hline
\end{tabular}

$*$ Certified information systems auditor or certified internal auditor.

\section{Design and procedure}

The experiment employs a $2 \times 2$ between-participants design, where the manipulated independent variables are audit committee expertise (low vs. high) and misstatement type (misstatement recognized vs. misstatement disclosed). Participants (i.e., Chief Audit Executives or Deputies) were randomly assigned to one of the four treatment conditions. The study was completed on paper and provided to participants in sealed envelopes by one of the study's authors. All participants completed the materials in their professional offices under controlled conditions in the presence of one of the authors.

Participants read a case study related to a recognized or disclosed misstatement and were asked to respond to the following dependent variable measure (note that only the recognition treatment included "recorded on the balance sheet" in the first dependent measure): Please select the amount of additional present value of capital lease liability that you would require to be [recorded on the balance sheet and] disclosed in the lease footnote $(0$, $10,20,30,40,50)$. Participants also responded to a series of debriefing questions, non-identifying demographic information, and questions associated with perceptions of the internal audit function. The case materials were adapted from Libby et al. (2006) to benchmark previously documented results for external audit partners against our results for CAEs and deputy CAEs.

We adopted the Libby, Nelson, and Hunton case and added a brief description related to the audit committee. The additional materials indicated that internal audit reports to both senior management and the audit committee. Participants were also informed of senior management's authority to make the decision to appoint or dismiss members of internal audit and the audit committee's authority to approve such decisions. This information was included to ensure that participants understood that they have responsibilities to report both to senior management and to the audit committee; that there is at least some level of dependence on senior management; and that the audit committee's background (i.e., size, frequency of meetings, and independence requirement) was in accordance with SOX and exchange listing requirements. 
Independent variables: financial reporting location and audit committee expertise The reporting location manipulation is the same manipulation employed in Libby et al. (2006). Participants were informed that new capital leases were accidentally omitted from the consolidated subsidiary balance sheet of Capital Auto Parts, Inc. Financial reporting location was manipulated by changing the type of lease agreement:

"However, evidence gathered by the internal audit staff indicates that some new [capital] [operating] leases at a consolidated subsidiary were accidentally omitted when Capital Auto Parts prepared their balance sheet and lease footnote, such that the present value of the [capital] [operating] lease amount is understated by $\$ 50$ million, which is equal to $4.6 \%$ of total assets. Management strongly objects to any adjustment of the statements and disclosures."

The size of the audit committee in the decision case is four members, which equals the average size of mediumsized public company audit committees (Huron Consulting Group., 2007). The low level of audit committee expertise quality was set to meet the minimum requirements for expertise created by the SEC's final definition of a financial expert. This definition allows non-accounting experts such as investment bankers, venture capitalists, and CEOs to meet the requirements of Section 407 of SOX (SEC, 2002). The case states:

... one member of the audit committee meets the minimum qualifications necessary to be considered a "financial expert," although this member does not have an accounting background.

We create the high level of audit committee expertise by indicating to participants that the majority of committee members are financial experts, using a more stringent definition of financial expert that is consistent with the initial definition of the SEC. This definition requires a financial expert to have experience preparing or auditing financial statements, and monitoring internal accounting controls and procedures for financial reporting (SEC, 2002). The case states:

... three of the four members are Certified Public Accountants, and these three members possess the qualifications necessary to be considered "financial experts".

\section{Results}

\section{Manipulation checks}

To check whether participants understood their task and their assigned conditions, two manipulation check questions were provided at the end of the case study. The first question asked if the error involved capital leases that were not recognized and disclosed or if the error involved operating leases that were not disclosed. The second question asked whether the audit committee included one member of the audit committee who met the minimum qualifications necessary to be considered a "financial expert" or if three of the four members of the audit committee were CPAs and possessed the qualifications necessary to be considered "financial experts." Two participants failed to correctly respond to both questions, and we retained these participants in all analyses. ${ }^{1}$

\section{Preliminary testing}

We included the demographic items in Table 1 as covariates in an ANCOVA model where the dependent variable was the amount of restatement correction and independent variables were financial reporting location (FRL), audit committee expertise (ACE), and an interaction term (FRL $\times$ ACE). One covariate was statistically significant in the model (years of internal audit experience). We retain this variable as a covariate in the model used to test hypotheses. The directions of means and results of hypotheses tests are unchanged if this covariate is removed. 


\section{Hypotheses tests}

The Analysis of Variance (ANOVA) model to test the hypotheses includes independent variables for financial reporting location ( $F R L)$, audit committee expertise (ACE), an interaction term (FRL $\times A C E)$ and the covariate described above. The amount of misstatement correction is the dependent variable. Results for Hypothesis 1 are presented in Table 2. Panel A displays the means and standard deviations for the amount of misstatement correction (across treatment conditions), and Panel B displays the ANOVA results. The main effect of financial reporting location is statistically significant $(p=0.010)$, and the pattern of means in Panel A indicates that participants require larger corrections for recognized misstatements (mean correction $=47.06$ ) than for disclosed misstatements (mean correction $=36.67$ ). Thus, the first hypothesis is supported.

Table 2. Amount of misstatement correction for different reporting locations.

\begin{tabular}{|c|c|c|c|c|c|}
\hline & & $\begin{array}{l}\text { Financial } \\
\text { reporting } \\
\text { location }\end{array}$ & & \multicolumn{2}{|c|}{$\begin{array}{l}\text { Main effect: } \\
\text { AC expertise }\end{array}$} \\
\hline & & nition & Disclosure & & \\
\hline \multicolumn{6}{|c|}{ Panel A: Mean $\{$ Sample Size $\}$ across treatment conditions ${ }^{\mathrm{a}}$} \\
\hline \multicolumn{6}{|c|}{ AC expertise } \\
\hline High & & $44.44\{18\}$ & $35.50\{20\}$ & \multicolumn{2}{|c|}{$38.93\{38\}$} \\
\hline Low & & $50.00\{16\}$ & $37.89\{19\}$ & \multicolumn{2}{|c|}{$43.43\{35\}$} \\
\hline Main effect: financial reporting location & & $47.06\{34\}$ & $36.67\{39\}$ & \multicolumn{2}{|c|}{$41.51\{73\}$} \\
\hline Source & $\begin{array}{l}\text { Sum of } \\
\text { square }\end{array}$ & d.f. & Mean square & $F$ & $p$ \\
\hline \multicolumn{6}{|l|}{$\begin{array}{l}\text { Panel B: ANOVA results (DV = amount of } \\
\text { misstatement correction) }\end{array}$} \\
\hline Financial reporting location (FRL) & 2122.61 & 1 & 2122.61 & 7.103 & 0.010 \\
\hline AC expertise (ACE) & 379.98 & 1 & 379.98 & 1.272 & 0.263 \\
\hline Interaction $(F R L \times A C E)$ & 12.92 & 1 & 12.92 & 0.043 & 0.836 \\
\hline Years of internal audit experience & 1135.67 & 1 & 1135.67 & 3.801 & 0.055 \\
\hline Error & 20319.56 & 68 & 298.82 & & \\
\hline
\end{tabular}

${ }^{a}$ Cell means represent the amount of misstatement correction required by participants (the means are adjusted for the three covariates). The variable was collected using the following scale: please select the amount of additional present value of capital lease liability that you would require to be [recorded on the balance sheet and] disclosed in the lease footnote $(0,10,20,30,40,50)$.

The second hypothesis is tested with the main effect of audit committee expertise on the amount of restatement correction. The main effect is not statistically significant $(p=0.263)$, and the results do not support hypothesis 2 . The interaction of audit committee expertise and financial reporting location is also not statistically significant $(p=0.836)$, and the results provide no support for the third hypothesis.

\section{Supplemental analyses}

In order to develop a more complete picture of the role of audit committee expertise in misstatement correction decisions, we also examine whether increased audit committee expertise increases internal auditors' perceptions of the audit committee's power over management. To analyze this issue, we again employ an ANOVA model that includes independent variables for financial reporting location (FRL), AC expertise (ACE), and an interaction term (FRL $\times$ ACE). In this model, perception of the audit committee's power is the dependent variable. Table 3, Panel A, shows the means and standard deviations for perceptions of the audit committee's power. The pattern of means reveals that participants, on average, perceive the AC to be more powerful in 
determining the amount of adjustment to lease liability when AC expertise is higher (1.00) relative to when AC expertise is lower (-1.11), and the main effect of AC expertise is statistically significant $(p=0.002)$.

Table 3. Internal auditors' perceptions of the audit committee's power vs. management's power.

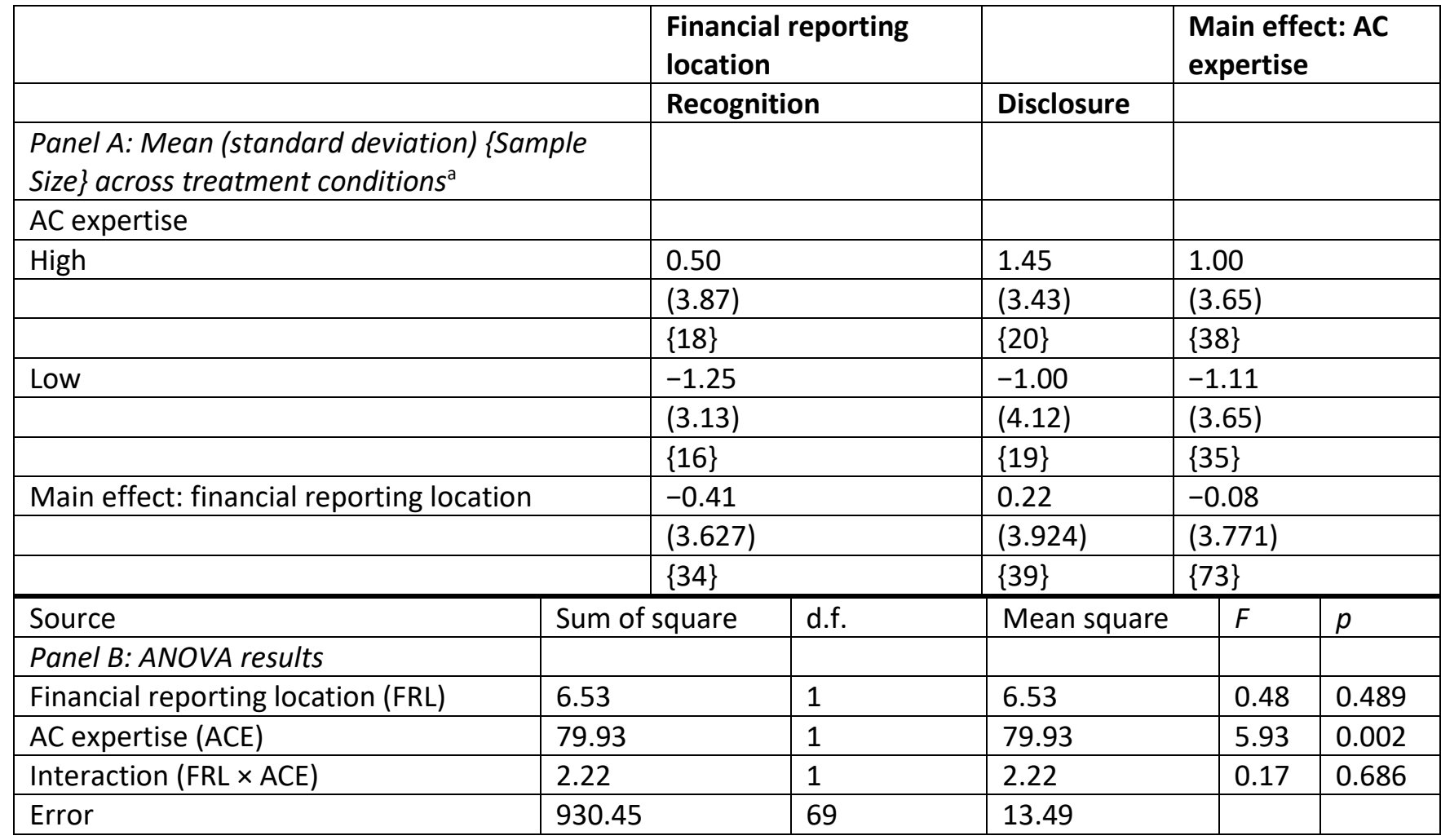

${ }^{a}$ Cell means represent perceptions of audit committee power. The variable was collected using the following scale: for the case you just completed, who do you believe had more power to determine the amount of adjustment to the lease liability, management or the audit committee? (Likert scale where $-5=$ management, $0=$ undecided, 5 = audit committee).

Contrary to our expectations, increased audit committee expertise did not result in internal auditors requiring larger misstatement corrections from management. However, CAEs and their deputies perceived that audit committee power increased when the audit committee had more financial expertise. Power theory suggests that internal auditors will feel empowered to require larger misstatement corrections when the audit committee has the power to reduce management's influence over the internal audit function. One potential explanation for our results is that CAE's do not perceive a need to exercise their power in order to correct disclosed misstatements. In other words, internal auditors, like external auditors, perceive that correction of disclosed misstatements is not as important as correction of recognized misstatements, and correcting disclosed misstatements is not worth the resulting conflicts with management.

\section{Debriefing analyses}

Subsequent to the case study, participants answered additional questions related to audit committee expertise and power perceptions (see Table 4). With respect to audit committee expertise, participants indicated that they are more willing to challenge management's financial reporting decisions when audit committees have more financial experts than when audit committees have fewer financial experts. However, as we discussed in the previous section, our experimental results suggest that this is not the case. Perhaps when CAEs are placed in an "actual scenario" where their relationship with management is threatened, CAEs decide that correcting disclosed misstatements is not critical enough to warrant conflicts with management. 
Table 4. Debriefing questions. ${ }^{\text {. }}$.

\begin{tabular}{|c|c|c|c|}
\hline Mean & $\begin{array}{l}\text { Standard } \\
\text { deviation }\end{array}$ & $\begin{array}{l}t- \\
\text { Statistic }\end{array}$ & $\begin{array}{l}p \text { - } \\
\text { Value }\end{array}$ \\
\hline \multicolumn{4}{|c|}{$\begin{array}{l}\text { 1. In general, are Chief Audit Executives more willing to challenge management's financial reporting decisions when } \\
\text { audit committees have greater levels of financial expertise, relative to when audit committees have lower levels of } \\
\text { financial expertise? (-5= not more willing at all, } 0=\text { undecided, } 5=\text { much more willing) }\end{array}$} \\
\hline 1.85 & 2.74 & 5.76 & 0.000 \\
\hline \multicolumn{4}{|c|}{$\begin{array}{l}\text { 2. In general, do you believe that the financial expertise of the audit committee is important for effectively } \\
\text { monitoring financial reporting? ( }-5=\text { not at all important, } 0=\text { undecided, } 5=\text { very important) }\end{array}$} \\
\hline 3.97 & 1.09 & 31.07 & 0.000 \\
\hline \multicolumn{4}{|c|}{$\begin{array}{l}\text { 3. In general, does the audit committee have more or less influence over financial reporting when the committee } \\
\text { has more members with high levels of financial expertise, relative to when the committee has few members with } \\
\text { financial expertise? ( }-5=\text { much less influence, } 0=\text { undecided, } 5=\text { much more influence) }\end{array}$} \\
\hline 3.14 & 1.48 & 18.17 & 0.000 \\
\hline \multicolumn{4}{|c|}{$\begin{array}{l}\text { 4. In general, does a Chief Audit Executive have the capacity to influence the audit committee's decisions related to } \\
\text { financial reporting? ( }-5=\text { not at all, } 0=\text { undecided, } 5=\text { very much) }\end{array}$} \\
\hline 2.27 & 1.92 & 10.10 & 0.000 \\
\hline
\end{tabular}

${ }^{a}$ All tests compare mean responses to the neutral mid-point of the scale.

Participants also considered that audit committee financial expertise is an important qualification for effectively monitoring financial reporting, and they believed that committee members with high levels of financial expertise have more influence over the financial reporting process than those with low levels of financial expertise. Finally, participants believed that the CAE has the capacity to influence audit committee decisions.

\section{Conclusions and implications}

External auditors who oversee the financial reporting process are less stringent when auditing disclosed lease obligations, relative to recognized obligations, in order to balance their conflicting incentives created by the risks of client loss vs. litigation/reputation risks (Libby et al., 2006). Similarly, our results suggest that internal auditors contribute to decreased reliability of disclosed amounts. It appears that the incentives of external auditors and internal auditors are closely aligned on this issue. In general, both of these parties seem to feel less responsibility for disclosed, relative to recognized amounts.

We proposed that increased audit committee expertise would decrease the influence of management on internal auditors' decisions and lessen internal auditors' incentives to waive misstatement corrections. The results of our experiment indicate that Chief Audit Executives (CAEs) do perceive the audit committee to be more powerful in the financial reporting process when the majority of the committee members have financial accounting expertise relative to when only one member has the minimum qualifications necessary to be a financial expert. However, the results indicate that CAEs do not choose to rely on the power created by audit committee expertise in order to require misstatement corrections. 
Given that prior research indicates that external auditors are willing to waive disclosed misstatements, there is evidence that most parties to the financial reporting decision process (i.e., management, external auditors, and internal auditors) face strong incentives to allow error and bias in disclosed amounts. Our findings also suggest that audit committee characteristics may have little effect on the existing incentives or the reliability of disclosed amounts. Like Libby et al. (2006), we find reason for serious concerns about the accuracy of disclosed amounts, relative to recognized amounts.

\section{Acknowledgements}

We thank participants of workshops at Bentley University, Eastern Illinois University, John Carroll University, Loyola Marymount University, Marquette University, Michigan Technological University, Southern Illinois University, and Western Illinois University for their comments and suggestions.

\section{References}

Arens et al., 2009. A. Arens, R. Elder, M. Beasley. Auditing and assurance service. An integrated approach. Prentice Hall, Upper Saddle River, NJ (2009) Bacharach and Lawler, 1980 S. Bacharach, E. Lawler. Power and politics in organizations. Jossey-Bass Publishers, San Francisco, CA (1980)

Barron et al., 2001. O. Barron, J. Pratt, J. Stice. Misstatement direction, litigation risk, and planned audit investment. Journal of Accounting Research, 39 (3) (2001), pp. 449-462

Braiotta, 2004. L. Braiotta. The audit committee handbook. John Wiley \& Sons, Hoboken, NJ (2004)

Braun, $2001 \mathrm{~K}$. Braun. The disposition of audit-detected misstatements: An examination of risk and reward factors and aggregation effects. Contemporary Accounting Research, 18 (1) (2001), pp. 71-99

Chadwick, 1995. W. Chadwick. Tough questions, tougher answers. The Internal Auditor, 52 (6) (1995), pp. 63-68

Drexler, 2003. P. Drexler. Beyond legislated interdependence. Internal Auditor, 60 (4) (2003), p. 104

Emerson, 1962. R. Emerson. Power-dependence relations. American Sociological Review, 27 (1962), pp. 31-41

Farmer et al., 1987. T. Farmer, L. Rittenberg, G. Trompeter. An investigation of the impact of economic and organizational factors on auditor independence. Auditing: A Journal of Practice and Theory, 7 (1) (1987), pp. 1-14

Financial Accounting Standards Board, 1980. Financial Accounting Standards Board (FASB), 1980. Statement of financial accounting concepts no. 2. Qualitative characteristics of accounting information. <http://www.fasb.org>.

Finkelstein, 1992. S. Finkelstein. Power in top management teams: Dimensions, measurement, and validation. Academy of Management Journal, 35 (1992), pp. 505-538

Glascock, 2002. K. Glascock. Auditees or clients? Internal Auditor, 59 (4) (2002), p. 84

Gramling et al., 2004. A. Gramling, M. Maletta, A. Schneider, B. Church. The role of the internal audit function in corporate governance. A synthesis of the extant internal auditing literature and directions for future research. Journal of Accounting Literature, 23 (2004), pp. 194-244

Harrington et al., 2005. L. Harrington, V. Melendez, A. Naylor, D. Burns. Siphoning the audit department. Internal Auditor, 62 (3) (2005), pp. 77-81

Huron Consulting Group, 2007. Huron Consulting Group. (2007). Audit committee research report. <http://www.huronconsultinggroup.com/library/auditcomreport_web.pdf >.

Institute of Internal Audit Research Foundation (IIARF), 2003a. Institute of Internal Audit Research Foundation (IIARF). (2003a). Internal audit independence and corporate governance. <http://www.theiia.org/iia/download.cfm?file=234> Accessed 01.12.09.

Institute of Internal Audit Research Foundation (IIARF), 2003b. Institute of Internal Audit Research Foundation (IIARF). (2003b). Internal audit reporting relationships: Serving two masters. 
<http://www.ifc.org/ifcext/corporategovernance.nsf/AttachmentsByTitle/Internal_Audit_Relationship/\$FILE/Internal_Auditing_Reporting_Relat ionships.pdf> Accessed 01.12.09.

Institute of Internal Audit Research Foundation, 2001. Institute of Internal Audit Research Foundation (IIARF). (2001). Independence and objectivity: A framework for internal auditors. Altamonte Springs, FL: IIARF. <http://www.theiia.org/bookstore/product/independence-and-objectivity-aframework-for-internal-auditors-1112.cfm> Accessed 01.12.09.

Institute of Internal Auditors (IIA), 2008. Institute of Internal Auditors (IIA). (2008). International standards for the professional practice of internal auditing (standards). <http://www.theiia.org/guidance/standards-and-guidance/ippf/standards/> Accessed 01.12.09.

Institute of Internal Auditors, 2002. Institute of Internal Auditors (IIA). (2002). Practice advisory 1110-2: Chief Audit Executive (CAE) reporting lines. $<$ http://www.iia.org.au/pdf/CombinedAdvisories.pdf> Accessed 01.12.09.

Jameson, 2006. S. Jameson. The CAE's many hats. Internal Auditor, 63 (4) (2006), pp. 35-37

Johnson, 2006. Johnson, S. (2006). Should internal audit report to the CFO? <http://cfosreact.com/article.cfm/8045574?f=related> Accessed 03.11.09.

Kalbers and Fogarty, 1993. L. Kalbers, T. Fogarty. Audit committee effectiveness: An empirical investigation of the contribution of power. Auditing: $A$ Journal of Practice and Theory, 12 (1) (1993), pp. 24-49

Kawashima, 2007. E. Kawashima. The hazards of consulting. Internal Auditor, 64 (6) (2007), pp. 80-81

KPMG, 2008. KPMG. (2008). Internal audit's role in effective corporate governance. <http://kpmg.com.au/Portals/0/IAS_Role-in-Corp-Gov200804.pdf>. Accessed 02.11.09.

Lawler and Bacharach, 1979. E. Lawler, S. Bacharach. Power dependence in individual bargaining: The expected utility of influence. Industrial \& Labor Relations Review, 32 (2) (1979), pp. 196-204

Libby and Kinney, 2000. R. Libby, W. Kinney. Does mandated audit communication reduce opportunistic corrections to manage earnings to forecasts? The Accounting Review, 75 (4) (2000), pp. 383-404

Libby et al., 2006. R. Libby, M. Nelson, J. Hunton. Recognition v. disclosure, auditor tolerance for misstatement, and the reliability of stockcompensation and lease information. Journal of Accounting Research, 44 (3) (2006), pp. 533-560

McHugh and Raghunandan, 1994. J. McHugh, K. Raghunandan. Hiring and firing the chief internal auditor. Internal Auditor, 51 (4) (1994), pp. $34-40$

Nelson et al., 2002. M. Nelson, J. Elliott, R. Tarpley. Evidence from auditors about managers' and auditors' earnings management decisions. The Accounting Review, 77 (Suppl.) (2002), pp. 175-202

Nelson et al., 2005. M. Nelson, S. Smith, Z. Palmrose. The effect of quantitative materiality approach on auditors' adjustment decisions. The Accounting Review, 80 (3) (2005), pp. 897-920

$\mathrm{Ng}$ and Tan, 2003. $\mathrm{T}$. Ng, H. Tan. Effects of authoritative guidance availability and audit committee effectiveness on auditors' judgments in an auditorclient negotiation context. The Accounting Review, 78 (3) (2003), pp. 801-818

Pfeffer, 1981. J. Pfeffer. Power in organizations. Ballinger Publishing Co, Cambridge, MA (1981)

Public Company Accounting Oversight Board, 2007. Public Company Accounting Oversight Board. (2007). Auditing standard no. 5: An audit of internal control over financial reporting that is integrated with an audit of financial statements. <http://www.pcaobus.org> Accessed 14.08.09.

Raghunandan et al., 2001. K. Raghunandan, W. Read, D. Rama. Audit committee composition, "gray directors", and interaction with internal auditing. Accounting Horizons, 15 (2) (2001), pp. 105-118

Ramos, 2006. M. Ramos. Practitioner's guide to GAAS 2007: Covering all SASs, SSAEs, SSARSs, and interpretations. John Wiley \& Sons, Hoboken, NJ (2006)

Rodgers, 2003. P. Rodgers. What we do best. Internal Auditor, 60 (2) (2003), p. 80 
Sarens and De Beelde, 2006a. G. Sarens, I. De Beelde. The relationship between internal audit and senior management: a qualitative analysis of expectations and perceptions. International Journal of Auditing, 10 (3) (2006), pp. 219-241

Sarens and De Beelde, 2006b. G. Sarens, I. De Beelde. Internal audit: the expert in providing comfort to the audit committee. The case of risk management and internal control. Working paper. Ghent University (2006)

Schipper, 2007. K. Schipper. Required disclosures in financial reports. The Accounting Review, 82 (2) (2007), pp. $301-326$

Scholz, 2008. Scholz, S. (2008). The changing nature and consequences of public company financial restatements: 1997-2006. The Department of the Treasury. <http://www.treas.gov/press/releases/reports/FinancialRestatements_1997_2006.pdf> Accessed 22.07.09.

Turley and Zaman, 2007. S. Turley, M. Zaman. Audit committee effectiveness: Informal processes and behavioral effects. Accounting, Auditing and Accountability Journal, 20 (5) (2007), pp. 765-788

US Securities and Exchange Commission (SEC), 2002. US Securities and Exchange Commission (SEC). (2002). Proposed rule: Disclosure required by sections 404, 406 and 407 of the Sarbanes-Oxley act of 2002. <http://www.sec.gov> Accessed 27.07.09.

Van Peursem, 2005. K. Van Peursem. Conversations with internal auditors: The power of ambiguity. Managerial Auditing Journal, 20 (5) (2005), pp. $489-512$

${ }^{1}$ Sensitivity tests indicate that the directions of mean differences are unaffected, and the statistical significance of some differences is strengthened when participants who incorrectly responded to the manipulation check questions are omitted from the sample. Thus, in order to present the most conservative findings, we retain all 73 participants who completed the experiment in our final sample. 